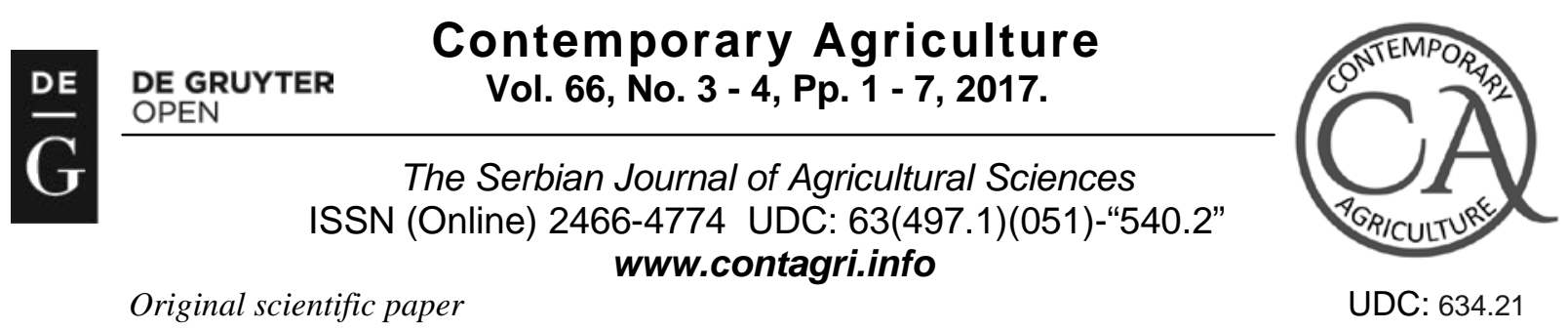

Original scientific paper

DOI:10.1515/contagri-2017-0012

\title{
SUITABILITY OF NOVI SAD APRICOT CULTIVARS AND SELECTIONS FOR COMPOTES
}

\author{
Dragan RAHOVIĆ ${ }^{1}$, Slavica ČOLIĆ ${ }^{1}$ Ivana BAKIĆ ${ }^{1}$, Sladjan STANKOVIĆ ${ }^{1}$, Aleksandra TEPIĆ
}

Summary: The paper presents the results of three-year research on technological properties of fruits and quality of compotes made of four Novi Sad (NS) apricot cultivars (NS-4, NS-6, Novosadska rodna and Novosadska kasnocvetna) and five selections (SK-1, SK-3, SK-5, SK 13a and SK 16a). Apricots for this research on technological properties and making compotes were harvested in a collection of apricot genotypes of the Department of Fruit Growing, Viticulture, Horticulture and Landscape Architecture of the Faculty of Agriculture in Novi Sad, in the site "Rimski šančevi" (45 $2000^{\circ}$ "N,19'51 100"E). Technological properties were investigated at the Faculty of Technology in Novi Sad and a laboratory of "Soja-Protein, AD Bečej" company. The investigated technological properties were: the amount of dry matter, total and reducing sugars, total acids, sucrose, total pectins, cellulose and mineral matter. These properties of NS cultivars and selections were compared to Hungarian Best (as a standard). The fruits of the NS cultivars and selections expressed better technological properties than Hungarian Best. The properties such as colour, aroma, taste, condition and consistency were sensory evaluated, with a method of giving points, used at the Novi Sad International Agricultural Fair. The compotes of the NS cultivars and selections were given more points than the compote made of standard. As for the total organoleptic properties, the compotes of selections SK-3, SK $13 a$ and SK-5 stand out.

Key words: apricots, cultivars, selections, technological properties of fruit, compote, sensory evaluation.

\section{INTRODUCTION}

Apricots are first-rate fruit for fresh consumption and valuable ingredients for industrial processing. A fine balance of nutrients gives them a high biological value. Apricots also have a significant commercial value, both when consumed fresh and when processed to make juices, compotes, jams, marmalade, fruit butter, preserves.

The most abundant ingredient in apricots is water. Water gives apricots juiciness and freshness and, consequently, a nice, plump and natural appearance. The most important sources of energy in apricots are sugars. Sugars give sweetness, while other elements enrich the taste. Apricots contain sugars in many forms. The most abundant is disaccharide-sucrose. The most common monosaccharide is glucose. Apricots contain a high amount of total acids, within a range from 0.9 to $2.09 \%$ (Rahović et al.,2009). According to the results of previous studies (Rahović, 2003; Milatović et al., 2005; Đurić and Keserović, 2007), apricots contain 10-16\% dry matter, 8-13\% sugar, $0.5-1.0 \%$ organic acids, $0.9 \%$ protein, $0.59 \%$ pectin, $0.03-0.27 \%$ tannin, $1.20 \mathrm{mg} / \%$ beta carotene (provitamin A), $7-10 \mathrm{mg} / \%$ vitamin C, mineral matter, $0.5 \%$ iodide and other nutrients.

End products made of apricots can be products with a relatively low amount of dry matter, such as compotes and mashes, or with a high amount of dry matter, such as jams, marmalade, candied fruit, juices and dried fruit.

Serbian food industry lacks high-quality fruit compotes, which were once a well-known export product. Our compote production is based on processing apricots, peaches, plums, sour cherries, cherries, pears and quince. It is rather fragmented production, with the use of conventional technological processes that result in compotes of average quality, without having a significant export brand. In order to restoring the positions we once had in compote production, besides introducing state-of-the-art technological lines into the process, it is also necessary to introduce the adequate cultivars, noting that not every cultivars is suitable for making compotes (Vračar, 2008). should not be too cooked or too hard; the aroma and taste of the compote should correspond to the fruit the compote is made of; the syrup should be clear or opalescent, in the amount that covers the fruit or the pieces of the fruit, and it should not contain any impurities. Due to technological quality, apricots are a valuable ingredient in production of compotes.

\footnotetext{
${ }^{1}$ Dragan Rahovic, PhD (Research Associate), Slavica Colic, PhD (Senior Research Associate), Sladjan Stankovic, PhD (research Associate), Ivana Bakic, PhD (Research Assistent), Institute for Science Application in Agriculture, Belgrade

${ }^{2}$ Aleksandra Tepic, PhD (Assistant Profesor), University of Novi Sad, Faculty of Tehnology

Corresponding author: Dragan Rahović, e-mail: drahovic@ipn.bg.ac.rs, tel +381 11 2-752-162
} 
After studying the suitability of certain apricot cultivars for compotes, Vračar et al. (1998) point out can be used to make compotes of outstanding quality.

The optimal time of harvest is vital for processing fresh apricots into compotes. It is very important to harvest the fruit when it is in the stage from medium to full technological maturity (Vračar, 2001, 2008; Vračar et al., 1998, 2005).

Commercial quality of apricots is strongly affected by the time of harvest. Early harvest is detrimental to the quality, since such fruit does not have full aroma, whereas late harvested fruit does not have good consistency (Mencarelli et al., 2006; Rossier et al., 2006; Valentini et al., 2006; Egea et al., 2006). Similar research was done by Robini et al. (2006), matching physical and chemical properties with sensory properties of fruit, as well as Bureau et al. (2006), studying the time of fruit maturing depending on physical, physiological and biochemical changes in fruits.

The effect of different time of harvest, physical and chemical changes in fruit during storage on the quality of apricots for the market of fresh products and the market of processed products was also the subject-matter of the research done by Dinnella et al. (2006) and Génard et al. (2006). All the above-mentioned have initiated the goal of this research: to compare pomological and technological properties of NS cultivars and selections of apricots with the leading cultivars Hungarian Best and, consequently, to make a selection of cultivars whose fruits can be a value ingredient for making compotes.

\section{MATERIAL AND METHODS}

The authors investigated technological properties of fruit and the quality of compotes made of four apricot cultivars: NS-4, NS-6, Novosadskarodna, Novosadskakasnocvetnaand five apricot selections:SK-1, SK-3, SK-5, SK $13 a$ and $S K 16 a$.

The apricots were harvested in aapricot genotypes collection of the Department of Fruit Growing, Viticulture, Horticulture and Landscape Architecture of the Faculty of Agriculture in Novi Sad, called "Rimskišančevi“.

The technological properties of apricot fruit and compotes were investigated at the Faculty of Technology in Novi Sad, at the Fruit and Vegetable Production Technology Lab. For a technological analysis 25 fruits were sampled from each cultivar and selection.

The amounts of potassium, calcium, sodium, magnesium, iron, zinc, and seleniumwere detected using the method of MET 408 and ICP-MS, and the amount of P by using 107-spectrophotometric method. Chemical analyses of mineral matter were made at the lab of "Soja-Protein AD Bečej" company.

The amount of soluble dry matter of fresh apricots was determined by an Abbe refractometer at $20^{\circ} \mathrm{C}$, and the total dry matter was dried in a laboratory dryer to constant weightat $103 \pm 2^{0} \mathrm{C}$.

The amount of sugar was determined with the Luff-Schoorl method.

Total acidity was determined with a standardized $\mathrm{NaOH}$ solution using phenolphthalein as an indicator; total aciditywas expressed as \% of malic acid.

The amount of total pectin was determined with the carbazole method.

The amount of total mineral matter (ash) was determined by the ignition of the oven-dried sample at $650^{\circ} \mathrm{C}$.

The technological properties of fruits of NS varieties and selections were compared to the properties of fruit of apricot varietyHungarian Best(standard).

Fruits for compotes were harvested in the stage of medium to full technological maturity. The fresh fruits were later, in laboratory conditions, processed into compotes, according to the following procedure:after washing and wiping, the fruits were manually cut into halves and pitted. The halves were then manually put into $720 \mathrm{ml}$ jars, keeping in mind that the fruit weight should be around $60 \%$ of jar volume. The jars were filled with hot $30 \%$ (300g sugar/700 $\mathrm{ml} \mathrm{H}_{2} \mathrm{O}$ )sugar syrupin the way that all the halves were covered with it. After putting the original lids, the jars were pasteurised at $85^{\circ} \mathrm{C}$, according to the equation:

$R p=\frac{10-20-10}{85^{\circ} \mathrm{C}}$;

Where:10 - represents the number of minutes in the heating stage; 20 - number of minutes in the stationary stageand10 - the number of minutes in the cooling stage.

Afterthe period of "equalisation" (one month), the compotes were given sensory grade for quality of the following properties: colour, aroma, taste, condition and consistency, with the grading method used at the Novi Sad International Agricultural Fair (Vračar, 2001). According to this method, certain criteria are given different number of points, and the total number of points is 20 (the scale for each compote trait is given in the heading of the table 2).In each year of the research, one jar of compote was made of each investigated apricot cultivar and selection. 
The sensory grade was given by an independent five-member expert board.The data were statistically analysed using the analysis of variance, while group testing - the F-test was used for individual comparisons.

\section{RESULTS AND DISCUSSION}

The Table 1 shows the technological properties of fruits of apricot cultivars and selections in the site "Rimski Sancevi"in the three-year period of research. The F-test did not detect that the year affected the chemical properties. The LSD test, however, showed a significant effect $(\mathrm{P}>0.05)$ of the year on the amounts of ash and cellulose, while all the chemical properties were affected by the cultivar except reducing sugars and cellulose.

The amount of dry matter in fruits is a parameter of their technological quality. The higher dry matter in fruits the higher their economic and use value. Compared to Hungarian Best, a significantly lower amount of dry matter (refract.) was recorded in SK-1. On the other hand, the amount of oven-dried dry matter was significantly lower in Novosadska rodna, SK-5, SK 13a and SK 16a, while it was highly significantly lower in NS-4 and SK-1, compared to Hungarian Best. According to Vračar (2001), minimal dry matter in apricot fruits (measured with a refractometer at 200C) that are used for industrial processing into certain products must be $10 \%$. According to this research, the average dry matter in NS cultivars and selections was higher, which implies that their fruits are potentially a good raw material for all kinds of processing. Regarding total acids, a significantly lower amount was recorded in SK-3, while SK 13a had significantly higher and NS-4 highly significantly higher dry matter than Hungarian Best. The amount of reducing sugars in all the investigated cultivars and selections was at the level of Hungarian Best.

Table 1. Technological properties of fruits of apricot cultivars and selections, "Rimski Sancevi“ (average)

\begin{tabular}{|c|c|c|c|c|c|c|c|c|c|c|c|c|}
\hline \multirow{2}{*}{ Sample } & \multicolumn{10}{|c|}{ Variety/Selection } & \multicolumn{2}{|c|}{ LSD } \\
\hline & NS-4 & NS-6 & $\begin{array}{c}\mathrm{N} . \\
\text { rodna }\end{array}$ & $\begin{array}{c}\mathrm{N} . \\
\text { kasno }\end{array}$ & SK-1 & SK-3 & SK-5 & $\begin{array}{l}\text { SK } \\
13 a \\
\end{array}$ & $\begin{array}{l}\text { SK } \\
16 a \\
\end{array}$ & $\begin{array}{c}\text { Hung. } \\
\text { Best }\end{array}$ & 0.05 & 0.01 \\
\hline $\begin{array}{l}\text { Dry mater } \\
\text { (refract.,\%) }\end{array}$ & 14.57 & 12.33 & 13.63 & 13.85 & 12.45 & 14.25 & 13.50 & 13.15 & 13.35 & 14.10 & 1.27 & 1.96 \\
\hline $\begin{array}{l}\text { Dry mater } \\
\text { (oven-dried, } \\
\% \text { ) }\end{array}$ & 15.87 & 13.16 & 14.31 & 14.85 & 13.36 & 15.55 & 14.21 & 13.84 & 14.22 & 15.42 & 0.97 & 1.5 \\
\hline $\begin{array}{l}\text { Acid } \\
\text { (\% malic } \\
\text { acid) } \\
\end{array}$ & 1.41 & 1.23 & 1.07 & 1.19 & 1.24 & 1.03 & 1.18 & 1.29 & 1.23 & 1.17 & 0.10 & 0.15 \\
\hline $\begin{array}{l}\text { Total sugar } \\
\text { (\%) }\end{array}$ & 11.15 & 11.21 & 11.54 & 10.39 & 10.17 & 11.07 & 10.94 & 10.69 & 10.36 & 11.18 & 0.61 & 0.94 \\
\hline $\begin{array}{l}\text { Reducing } \\
\text { sugars (\%) }\end{array}$ & 5.34 & 5.80 & 6.11 & 5.22 & 5.14 & 5.74 & 5.34 & 5.29 & 5.18 & 5.51 & 0.89 & 1.37 \\
\hline Sucrose (\%) & 3.73 & 3.65 & 4.19 & 2.98 & 3.73 & 3.91 & 4.65 & 4.18 & 3.30 & 3.60 & 0.65 & 1.00 \\
\hline Ash (\%) & 0.64 & 0.54 & 0.66 & 0.81 & 0.47 & 0.42 & 0.33 & 0.75 & 0.49 & 0.57 & 0.17 & 0.26 \\
\hline Pectin (\%) & 0.61 & 0.72 & 0.70 & 0.67 & 0.66 & 0.56 & 0.58 & 0.84 & 0.65 & 0.54 & 0.17 & 0.26 \\
\hline Cellulose (\%) & 0.57 & 0.58 & 0.60 & 0.68 & 0.56 & 0.53 & 0.53 & 0.64 & 0.54 & 0.56 & 0.07 & 0.11 \\
\hline $\mathrm{K}(\mathrm{mg} / 100 \mathrm{~g})$ & 213.55 & 210.05 & 219.85 & 206.30 & 217.30 & 222.70 & 211.50 & 213.70 & 201.60 & 202.30 & 4.14 & 6.37 \\
\hline Ca (mg/100g) & 16.03 & 20.98 & 12.29 & 15.41 & 18.63 & 19.85 & 19.12 & 19.20 & 19.31 & 10.48 & 0.34 & 0.52 \\
\hline $\mathrm{Na}(\mathrm{mg} / 100 \mathrm{~g})$ & 1.92 & 1.91 & 2.38 & 2.31 & 2.35 & 2.23 & 2.15 & 2.21 & 2.41 & 1.53 & 0.10 & 0.15 \\
\hline $\mathrm{P}$ (mg/100g) & 19.0 & 20.6 & 18.2 & 17.8 & 15.0 & 19.0 & 16.0 & 24.0 & 22.0 & 16.9 & 0.57 & 0.87 \\
\hline $\begin{array}{l}\mathrm{Mg} \\
(\mathrm{mg} / 100 \mathrm{~g})\end{array}$ & 10.14 & 11.81 & 10.45 & 9.68 & 12.23 & 12.34 & 11.82 & 11.40 & 12.56 & 9.00 & 0.77 & 1.19 \\
\hline $\mathrm{Fe}(\mathrm{mg} / 100 \mathrm{~g})$ & 0.63 & 0.41 & 0.30 & 0.38 & 0.34 & 0.46 & 0.45 & 0.48 & 0.49 & 0.33 & 0.11 & 0.18 \\
\hline Zn (mg/100g) & 0.127 & 0.160 & 0.087 & 0.088 & 0.080 & 0.083 & 0.076 & 0.088 & 0.081 & 0.094 & 0.010 & 0.015 \\
\hline Se (mg/100g) & 0.0061 & 0.0050 & 0.0009 & 0.0008 & 0.0006 & 0.0008 & 0.0007 & 0.0007 & 0.0005 & 0.0005 & 0.0003 & 0.0005 \\
\hline
\end{tabular}

Novosadska 4 (NS-4); Novosadska 6 (NS-6); Novosadska rodna (N. rodna); Novosadska kasnocvetna (N. kasno); Selekcija kajsije 1 (SK-1); Selekcija kajsije 3 (SK-3); Selekcija kajsije 5 (SK-5); Selekcija kajsije 13 a (SK13a); Selekcija kajsije 16a (SK-16a); Mađarska najbolja (Hung. Best). 
The amount of ash was significantly higher in Novosadska kasnocvetna, whereas the level of total pectin was significantly higher in NS-4 and highly significantly higher in SK-13a. SK-5 was distinguished for sucrose, having a highly significantly higher amount of sucrose than Hungarian Best. While sucrose prevails in the structure of sugars, the percentage of the main acids significantly varies, which correlates with taste, sweetness and juiciness of the fruits. The investigated cultivars had well-balanced ratio between the sugars and the acids, although different proportions between the main acids can affect the taste. The results obtained in this research are mainly in line with the values of the most important mineral elements in fruits of NS cultivars and selections reported by other researchers (Korać et al. 2000; Vračar et al., 2005; Đurić et al., 2005; Keserović et al., 2005; Đurić and Keserović, 2007; Rahović et al., 2009; Mratinić et al., 2010).

The highest average amount of ash and cellulose was recorded in variety Novosadska kasnocvetna (ash $0.82 \%$, cellulose $0.68 \%$ ), and lowest selection SK-1 (ash $0.23 \%$ and cellulose $0.53 \%$ ), whereas total pectins were highest in selection SK 13a (0.84\%) and lowest in variety Hungarian Best $(0.54 \%)$. The fruit of NS apricot varieties and selections is characterised by its significant amount of mineral matter. The amount of potassium $(\mathrm{K})$ ranged from 201.60 (SK 16a) to 222.70 (SK-3). Compared to Hungarian Best, all the varieties and selections had on average a higher amount of potassium, except SK 16a. The fruits of NS cultivars and selections are characterised by a considerable amount of mineral matter. Testing of significance showed some statistically highly significant differences among the cultivars in the amount of mineral matter. The amount of potassium (K) ranged from 201.60 (SK 16a) to 222.70 (SK-3). When compared to Hungarian Best, all the cultivars and selections had on average higher amounts of potassium, except for SK 16a. Testing the differences also showed that the amount of potassium (K) in Novosadska kasnocvetna and SK 16a was at the level of the standard, while the other investigated cultivars and selections had statistically significantly higher amounts. The amount of calcium (Ca) was highest in SK 16a (20.98) and lowest in Hungarian Best (10.48); likewise, the amount of sodium (Na) was highest in SK 16a and lowest in Hungarian Best. It was determined that all the investigated cultivars and selections had significantly higher amounts of calcium and sodium than Hungarian Best.The highest amount of magnesium (Mg) was recorded in SK16, and the lowest in Hungarian Best. The amount of phosphorous (P) ranged from 15.0 (SK-1) to 24.0 (SK 13a). Testing of differences showed that the amount of magnesium in Novosadska kasnocvetna was at the level of the standard, while a significantly higher amount of magnesium was recorded in the other investigated cultivars and selections. SK-1 and SK-5 had the amount of phosphorous at the level of the standard, while the other investigated cultivars and selections had statistically significantly higher amounts of phosphorous than Hungarian Best. The amount of iron (Fe) in NS-6, Novosadska rodna, Novosadska kasnocvetna, SK-1 and SK-5 was at the level of standard, whereas the other cultivars and selections had significantly higher amounts of iron than Hungarian Best.NS-4 had the highest amount of selenium (Se), and NS-6 the highest amount of zinc (Zn). The amounts of selenium and zinc were significantly higher in NS-4 and NS-6, while in the other investigated cultivars and selections they were at the level of Hungarian Best. It can be seen that the NS cultivars and selections of apricots mostly have higher amounts of mineral elements than Hungarian Best.

Table 2. Sensory grade of compotes made of fruits of apricot cultivars and selections, number of points, "Rimski Sancevi" (average)

\begin{tabular}{|l|c|c|c|c|c|c|}
\hline \multicolumn{1}{|c|}{ Variety/Selection } & \multicolumn{6}{c|}{ Compote properties - number of points } \\
\hline & \begin{tabular}{c} 
Colour \\
\multicolumn{1}{|l}{$(1-3)$}
\end{tabular} & $\begin{array}{c}\text { Aroma } \\
(1-3)\end{array}$ & $\begin{array}{c}\text { Taste } \\
(1-6)\end{array}$ & $\begin{array}{c}\text { Condition } \\
(1-3)\end{array}$ & $\begin{array}{c}\text { Consistency } \\
(1-5)\end{array}$ & Total \\
\hline NS-4 & 2.6 & 2.8 & 5.0 & 2.4 & 3.7 & 16.5 \\
\hline NS-6 & 2.6 & 2.6 & 5.3 & 2.4 & 3.9 & 16.8 \\
\hline N. rodna & 2.8 & 2.6 & 4.7 & 2.5 & 3.7 & 16.3 \\
\hline N. kasnocvetna & 2.7 & 2.7 & 4.7 & 2.5 & 4.1 & 16.7 \\
\hline SK-1 & 2.6 & 2.7 & 4.5 & 2.5 & 4.3 & 16.6 \\
\hline SK-3 & 2.7 & 2.8 & 5.2 & 2.6 & 4.4 & 17.7 \\
\hline SK-5 & 2.8 & 2.7 & 4.9 & 2.6 & 4.1 & 17.1 \\
\hline SK 13a & 2.8 & 2.8 & 5.2 & 2.5 & 4.0 & 17.3 \\
\hline SK 16a & 2.4 & 2.6 & 4.6 & 2.5 & 3.9 & 16.0 \\
\hline Hungarian best & 2.5 & 2.5 & 4.9 & 2.3 & 3.9 & 16.1 \\
\hline LSD 0.05 & 0.3 & 0.2 & 0.4 & 0.3 & 0.4 & \\
\hline LSD 0.01 & 0.4 & 0.4 & 0.5 & 0.4 & 0.6 & \\
\hline
\end{tabular}


Novosadska 4 (NS-4); Novosadska 6 (NS-6); Novosadska rodna (N. rodna); Novosadska kasnocvetna (N. kasnocvetna); Selekcija kajsije 1 (SK-1); Selekcija kajsije 3 (SK-3); Selekcija kajsije 5 (SK-5); Selekcija kajsije 13 a (SK-13a); Selekcija kajsije 16a (SK-16a); Mađarska najbolja (Hungarian Best).

The sensory grade is very important in evaluating the quality of a product. Sensory attributes are fruit properties that can be examined or evaluated by human senses: colour, aroma, taste, consistency and the overall condition of a product (Vračar, 2001). Table 2 shows the average number of points after giving sensory grades to apricot compotes for each property of the compote, and the total number of points, for three years of research. The colour of products is a very important factor of quality and a sensory grade, since colour nuances can help us successfully determine the level of fruit maturity. The number of points for the colour of the compotes ranged from 2.4 to 2.8 , out of 3 . Observed by cultivars and selections, the highest number of points was given to the compotes made of Novosadska rodna, SK-5 and SK 13a (2.8), then Novosadska kasnocvetna and SK-3 (2.7), NS-4, NS-6 and, finally, selections SK-1 (2.6), Hungarian Best (2.5) and SK 16a (2.4). Testing for significance of differences for compote colour, it was determined that the colour of the compotes made of the fruits of Novosadska rodna, SK-3 and SK-5 significantly differed from the standard, while the colour of the compotes made of the other cultivars and selections were at the level of the standard. The aroma of products is satisfactory if it corresponds to the natural aroma of the fruit the product is made of. The number of points for aroma ranged from 2.5 to 2.8, out of 3. Observed by cultivars and selections, the highest number of points was given to the compotes made NS-4, SK-3 and SK 13a (2.8), than the compotes of Novosadska kasnocvetna, SK-1 and SK-5 (2.7), NS-6, Novosadska rodna and SK 16a (2.6) and Hungarian Best (2.5). When compared to the aroma of the Hungarian Best compote, the aroma of the compotes made of NS-4, NS-6, SK-1 and SK-5 was significantly different, whereas the aroma of the compotes made of the other cultivars and selections was at the level of the standard.

The taste of products is the key parameter, based on which food can be evaluated as satisfactory or not satisfactory. The number of points given for the taste ranged from 4.5 to 5.3, out of 6 . The highest number of points was given to the compote made of NS-6 (5.3), than to the compotes made of SK-3 and SK 13a (5.2), NS-4 (5.0), Hungarian Best and SK-5 (4.9), Novosadska rodna and Novosadska kasnocvetna (4.7), SK 16a (4.6) and SK-1 (4.5).

The overall condition of products is also the parameter for the sensory grade. What is evaluated is the unification of fruits in terms of their shape and size in the compotes, as well as the clearness of the compotes. The number of points given for the condition of the compotes ranged from 2.3 to 2.6, out of 3 . The highest number of points was given to the compotes made of SK-3 and SK-5 (2.6), than the compotes made of Novosadska rodna, Novosadska kasnocvetna, SK-1, SK 13a and SK 16a (2.5), NS-4 and NS-6 (2.4), and Hungarian Best (2.3).The taste and the overall condition of the compotes made of all the investigated cultivars and selections were at the level of the standard.

Regarding consistency, the number of points ranged from 3.7 to 4.4, out of 5. The highest number of points was given to the compote made of SK-3 (4.4), than to SK-1 (4.3), Novosadska kasnocvetna and SK-5 (4.1), NS-6, SK 16a, SK 13a and Hungarian Best (3.9), and, finally NS-4 and Novosadska rodna (3.7).On average, for all three years of research, the total number of points ranged from 16 (SK 16a) to 17.7 (SK-3), out of 20. Compared to the average number of points given to the compotes made of Hungarian Best (16.1), the compotes of all the NS cultivars and selections were given more points, except SK 16a, with the number of points in the range of the standard. Regarding the condition of the compotes, the highest number of points was given to SK-3 and SK-5, then Novosadska rodna, Novosadska kasnocvetna, SK-1, SK 13a, SK 16a, NS-4, NS-6 and Hungarian Best. There was a significantly higher difference in the overall condition of Novosadska kasnocvetna and SK-1 when compared to Hungarian Best, while the condition of the other investigated cultivars and selections was at the level of the standard. When it comes to the average number of points, the compotes of all the NS cultivars and selections were given more points than the standard, except SK 16a that had fewer points than the standard. The compotes of SK-3, SK 13a and SK-5 stand out due to high number of points given for the total organoleptic properties. .

\section{CONCLUSION}

Based on three-year research on technological properties of apricots and suitability of NS cultivars and selections for making compotes, one can draw the following conclusions: 
1. Dry matter determined with the refractometric method and oven-drying was highest in varietie NS-4; total and reducing sugars were highest in variety Novosadska rodna, sucrose in selection SK-5, and total acids in variety NS-4.

2. NS cultivars and selections mostly have higher amounts of key mineral elements than Hungarian Best.

3. Fresh apricots were used to make so-called "sweet compotes" in laboratory conditions.

4. The highest number of points in sensory evaluation of apricot compotes was given to selection SK-3.

5. The compotes of NS cultivars and selections were given more points than the standard, except the compote made of selection SK 16a, the number of points of which was in the range of the standard.

6. The compotes of selections SK-3, SK 13a and SK-5 stand out due to their organoleptic properties.

\section{REFERENCES}

BUREAU, S., CHAHINE, H., GOUBLE, B., REICH, M., ALBAGNAC, G., Audergon, J.M.: Fruit ripering of conntrasted apricot varieries: Physical, Physiological and Biochemical changes. Acta Hort., 701:511-516, 2006.

DINNELLA, C., CICCO, N., GARGARO, M.T., MONTELEONE, E., INFANTINO, V., LATTANZIO, V., XILOYANNIS, C.: Influences of ripening stage on quality indexes in apricot for fresh market and. Acta Hort., 701: 523-528, 2006.

ĐURIĆ, B., KESEROVIĆ, Z., KORAĆ, M.,VRAČAR, Lj.: Nove sorte kajsije u Vojvodini. Voćarstvo, 39(15)279-284, 2005. ĐURIĆ, B., KESEROVIĆ, Z.: Gajenje kajsije. Treće prošireno izdanje. Poljoprivredni fakultet, Novi Sad, 2007.

EGEA, J., ROMOJARO, F., PRETEL, M.T., MARTINEZ-MADRID, M.C., COSTELL, E., CASCALES, A.: Application of sensory analysis to the determination of the determination of the optimum quality and harvesting moment in apricots. Acta Hort., 701: 529-532, 2006.

GÉNARD, M., LESCOURRET, F., AUDERGON, J.M., REICH, M., ALBAGNAC, G.: Modeling the apricot sugar contents in relation to fruit growth. Acta Hort., 701: 517-522, 2006.

KESEROVIĆ, Z., ĐURIĆ, B., KORAĆ, M: Sorte i selekcije kajsije u Vojvodini. Zbornik sažetaka sa Naučno-stručnog savetovanja agronoma Republike Srpske-Poljoprivreda RS kao sastavni deo evropskih integracionih procesa, Jahorina, 2005. KORAĆ, M., KORAĆ, J., CEROVIĆ, S., GOLOŠIN, B.: Kajsija-Novosadska rodna. Savremena poljoprivreda, 49 (vanredni broj) 29-31, 2000.

MENCARELLI, F., BOTONDI, R., DE SANTIS, D., VIZOVITIS, K.: Post-harvest quality maintenance of fresh apricots. Acta Hort., 701: 503-510, 2006.

MILATOVIĆ, D., ĐUROVIĆ, D., MILIVOJEVIĆ, J.: Biološke osobine srednje poznih sorti kajsije u beogradskom području. Voćarstvo, 39(151)301-311, 2005.

MRATINIĆ, E., MILATOVIĆ, D., ĐUROVIĆ, D.: Biološke osobine domaćih sorti i selekcija kajsije gajenih u beogradskom Podunavlju. Voćarstvo, 44(169-170)13-19, 2010.

RAHOVIĆ, D.: Pomološko-tehnološke osobine plodova kajsije u beogradskom području. Jugoslovensko voćarstvo, 37(141142)13-18, 2003.

RAHOVIĆ, D., Čolić, S., Bakić, I.: Hemijske osobine novosadskih sorti i selekcija kajsije. Poljoprivredne aktuelnosti, 3-4: 7682, 2009.

ROBINI, K., HASHIM, L., LADEVEZE, D., BUREAU, S., GOUBLE, B., REICH, M., JACQUEMIN, G., ALBAGNAC, G., GURRIERI, F., AUDERGO, J.M.: Prediction of sensory data by instrument measurements of representative apricot (Prunus armeniaca L.) varieties. Acta Hort., 701: 533-540, 2006.

ROSSIER, J., DARBELLAY, C., AZODANLOU, R., VILLETTAZ, J.C.: Measurement of organoleptic quality of apricot. Acta Hort., 701: 575-576, 2006.

VALENTINI, N., MELLANO, M.G., ANTONIONI, I., BOTTA, R.: Chemical, physical and sensory analysis for evaluating quality of apricot varieties. Acta Hort., 701: 559-564, 2006.

VRAČAR, LJ., ĐURIĆ, B., KESEROVIĆ, Z.: Pogodnosti nekih sorti kajsija za proizvodnju kompota. III Jugoslovenski simpozijum prehrambene tehnologije, Beograd, 63-68, 1998.

VRAČAR, LJ.: Priručnik za kontrolu kvaliteta svežeg i prerađenog voća, povrća i pečurki i osvežavajućih bezalkoholnih pića. Tehnološki fakultet, Novi Sad, 2001.

VRAČAR, Lj., TEPIĆ, A., KESEROVIĆ, Z.: Technological characteristics of apricot selections from Novi Sad, XIII ${ }^{\text {th }}$ International Symposium on Apricot Breeding and Culture, Murcia, Spain, 2005.

VRAČAR, Lj.: Prerada voća-plenarno predavanje na XIII kongresu voćara i vinogradara Srbije, 2008. 


\title{
POGODNOST NOVOSADSKIH SORTI I SELEKCIJA KAJSIJE ZA PROIZVODNJU KOMPOTA
}

\author{
Dragan RAHOVIĆ, Slavica ČOLIĆ, Ivana BAKIĆ, Slađan STANKOVIĆ
}

Rezime. U radu su predstavljeni trogodišnji rezultati ispitivanja tehnoloških osobina ploda i kvaliteta kompota od četiri novosadske sorte (NS-4, NS-6, Novosadska rodna i Novosadska kasnocvetna) i pet selekcija kajsije (SK-1, SK-3, SK-5, SK 13a i SK 16a). Plodovi kajsije, za ispitivanje tehnoloških osobina i spravljanje kompota, brani su u kolekcionom zasadu kajsije Departmana za voćarstvo, vinogradarstvo, hortikulturu i pejzažnu arhitekturu Poljoprivrednog fakulteta u Novom Sadu, na lokalitetu „Rimski Šančevi“. Tehnološke osobine ploda ispitivane su na Tehnološkom fakultetu u Novom Sadu i Laboratoriji „Soja-Protein, AD Bečej. Od tehnoloških osobine ploda ispitivan je sadržaj suve materije, ukupnih i redukujućih šećera, ukupnih kiselina, saharoze, ukupnih pektina, celuloze i mineralnih materija. Tehnološke osobine ploda novosadskih sorti i selekcija kajsije upoređivane su sa Mađarskom najboljom (standard). Plodovi novosadskih sorti i selekcije kajsije ispoljili su bolje tehnološke osobine od Mađarske najbolje. Senzorska ocena kvaliteta kompota za osobine: boja, miris, ukus, stanje i konzistencija, vršena je metodom bodovanja koja se primenjuje na Međunarodnom poljoprivrednom sajmu u Novom Sadu. Kompoti novosadskih sorti i selekcija kajsije osvojili su više bodova od standarda. Po ukupnim organoleptičkim osobinama ističu se kompoti selekcija SK-3, SK 13a i SK-5.

Ključne reči: kajsija, sorte i selekcije, tehnološke osobine ploda, kompot, senzorna ocena

\section{Received / Primljen: 05.04.2017. Accepted / Prihvaćen: 30.07.2017.}

